\title{
A Study on Different Arabian Date Palm (Phoenix dactylifera L.) Accessions in Bangladesh
}

\author{
M. J. U. Khan, M. Billah and M. A. Latif* \\ Department of Genetic and Plant Breeding, Patuakhali Science and Technology University, Dumki, \\ Patuakhali-8602, Bangladesh \\ *Corresponding author and Email: malatif_pstubd@yahoo.com
}

Received: 04 April $2015 \quad$ Accepted: 12 December 2015

\begin{abstract}
A pot experiment was conducted at Patuakhali Science and Technology University, Dumki, Patuakhali during April 2013 to May 2014 to study the survival abilities of 10 Arabian date palm accessions in Bangladesh. The experiment was laid out in a two factors (ten accessions and three pot mixtures) in the Completely Randomized Design (CRD) with three replications. There were significant differences in various traits among the genotypes. The time required for germination was the lowest for Dubai small but the highest for Dabash. The time required the completion of germination of saplings was the least for Deglet Nour (Algeria) and the highest for Marium (Algeria). The highest number of leaves was found in the Deglet Nour (UAE) and the lowest was in Farida. After 12 months, the tallest plant was measured for Dubai small but the shortest was for Deglet Nour (UAE). The highest plant vigour after 12 months was found in Deglet Nour (Saudi), while the lowest was in the Deglet Nour (UAE). Among the three pot mixtures, soil : cowdung $=1: 1$, showed best results for plant height and vigour.
\end{abstract}

Keywords: Arabian date palm, vigour, germination, sapling, performance

\section{Introduction}

Date palm (Phoenix dactylifera L.) was house broken some 6,000 years ago in the Mesopotamian region as noted from archaeological evidence (Zohary and Hopf, 2000). It has been established as an important food crop in the desert regions of Arabian countries and has become the basis of survival of many ancient nomads (Mohammed et al., 1983). At present, its more than 2000 cultivars of date palm are known to exist all over the world (Askari et al., 2003) but only a limited important ones have been valued for their agronomic and fruit qualities (Al-Hooti et al., 1997). The fresh date markets embrace Bangladesh, Canada, Denmark, Germany, India, Indonesia, Malaysia,
South Africa, Sri Lanka, USA and UK whereas the dried dates are traded to Afghanistan, Bangladesh, Canada, Denmark, Germany, India and Japan (Amin et al., 2007). During the colonial period, a number of Arabian date palm varieties were introduced in Multan and Muzaffargarh, in Punjab during 1910-12 from Basra (Iraq) by the British Indian Government (Milne, 1918). The importance of date palm culture for its high nutritive, economic and social values is well recognized, especially in the arid and semi-arid areas, where it plays an important role. Global production, utilization and industrialization of dates are increasing continuously (Botes and Zaid, 2002); its world production expanded from 1.8 million tons in 1961 to 5.4 million tons in 2001 with an annual 
expansion of about 5\%. Local date palm (Phoenix sylvestris Roxb.) in Bangladesh is the main source of only jaggary (gur) as its fruit quality is poor. So, every year Bangladesh spends huge foreign currency to import date palm from the Middle-East. Millions of date palm trees got lost within one decade in North Africa due to different natural disasters (Baaziz et al., 2000). That event suggests that large numbers of traditional cultivars in many countries may be lessening. Therefore urgent conservation efforts are needed worldwide (Chao and Krueger, 2007). Introduction of new varieties from the native places to check their adaptability under varied environments is of an utmost importance. Recently high quality date production in Valuka of Mymensingh district conveys an excellent message for this country as a glimp of success. The planted palm species exhibited good growth at the early stage in the foreshore coastal lands (Islam et al., 2014).

Hence, detail studies are needed about this problem. But research works on it is little in Bangladesh. So, this study was undertaken to:

(i) evaluate the germination capability of seeds of 10 Arabian date palm accessions collected from local and exotic sources;

(ii) evaluate the survival capacity of saplings of these accession sand finally; and

(iii) select suitable genotype especially for the saline prone coastal area of Bangladesh.

\section{Materials and Methods}

This work was carried out at the campus of Patuakhali Science and Technology University (PSTU), Patuakhali district, Bangladesh during April 2013 to May 2014. Geographically, the experimental area is located at $22^{\circ} 37^{\prime} \mathrm{N}$ latitude and $89^{\circ} 10^{\prime} \mathrm{E}$ longitudes. The area is within the Gangetic Tidal Flood Plains and lies at 0.9 to 2.1 meter above the mean sea level (Iftekharand Islam, 2004). The experimental area is situated in the sub-tropical climatic zone characterized by heavy rainfall during April to September (Kharif Season) and scanty rainfall during the rest period of the year (Biswas, 1987). During April 2013 to April 2014, the average mean temperature was $26.87{ }^{\circ} \mathrm{C}$, air relative humidity was $81.69 \%$ and the average rainfall was 130.15 $\mathrm{mm}$ (Meteorological department of Patuakhali unpublished data).

\subsection{Description of the experimental materials}

The seeds of the 10 Arabian date palm accessions used as the study are given in Table 1.

\subsection{Experimental design and layout, Seed soaking, incubation and sowing}

Seeds were soaked with water for 1, 2 and 3 days and incubated in an incubator at $30{ }^{\circ} \mathrm{C}$. Within 711 days seeds got sprouted. Then those sprouted seeds were sown into poly bags $(18 \mathrm{~cm} \mathrm{X} 10 \mathrm{~cm})$ at the depth of $1-2 \mathrm{~cm}$.

Table 1. Identities of 10 Arabian date accessions used in the study

\begin{tabular}{cll}
\hline Accession no. & Name of the variety & Country of origin \\
\hline V1 & Deglet Nour (UAE) & United Arab Emirates \\
V2 & Deglet Nour (Algeria) & Algeria \\
V3 & Deglet Nour (Saudi) & Saudi Arabia \\
V4 & Borhi & United Arab Emirates \\
V5 & Marium (Algeria) & Algeria \\
V6 & Nagal & Saudi Arabia \\
V7 & Normal & Iraq \\
V8 & Farida & Saudi Arabia \\
V9 & Dabash & United Arab Emirates \\
V10 & Dubai (small) & United Arab Emirates \\
\hline
\end{tabular}


Three pot mixtures used was as follows- $S_{1}$ (Sand: Cowdung = 1:1), $\mathrm{S}_{2}$ (Soil: Cowdung = 1:1) and $S_{3}$ (Sand: Soil: Cowdung $=1: 1: 1$ ); because date thrives in sand, sandy loam, clay and other heavy soils too (Morton, 1987). After three months saplings were transplanted into pots $(10$ L) filled with the pot mixture as per experimental design. The experiment was laid out in a factorial Completely Randomized Design (CRD) with three replications, (three pot mixtures and ten genotypes). Thus, there were 90 unit pots.

\subsection{Data collection and analyses}

Data were collected on time required for sprouting, germination percentages, time required for completion of germination, days required for two leaf state; number of leaves, plant height and plant vigour (in 5 scale) after 6 and 12 months. The collected data were analyzed statistically using MSTATC and SIGMA PLOT program. The data recorded for each trait were then averaged to obtain means and the analysis of variance was performed using those mean values. Finally, Duncan's Multiple Range Test (DMRT) was done to separate the mean.

\section{Results and Discussion}

\subsection{Time required for completion of germination}

The range of germination percentage lies between 0-96 and the average germination percentage was $73 \%$. The highest germination (84\%) was found from in the immersion of seeds in normal water and sun heated water for $12 \mathrm{~h}$ (Azad et al., 2011). Figure 1 shows that the least time required for germination was for the accessions no. $\mathrm{V}_{5}, \mathrm{~V}_{6}$ and $\mathrm{V}_{10}$ while the lowest time required for completion of germination was obtained from $\mathrm{V}_{2}, \mathrm{~V}_{4}, \mathrm{~V}_{6}$ and $\mathrm{V}_{9}$ with the same pot mixture of sand: Cowdung $=1: 1$. Seed germinated with course sand and mixture of coarse and fine sand at a ratio of 3:1 was better than the loamy soil (Azad et al., 2011).

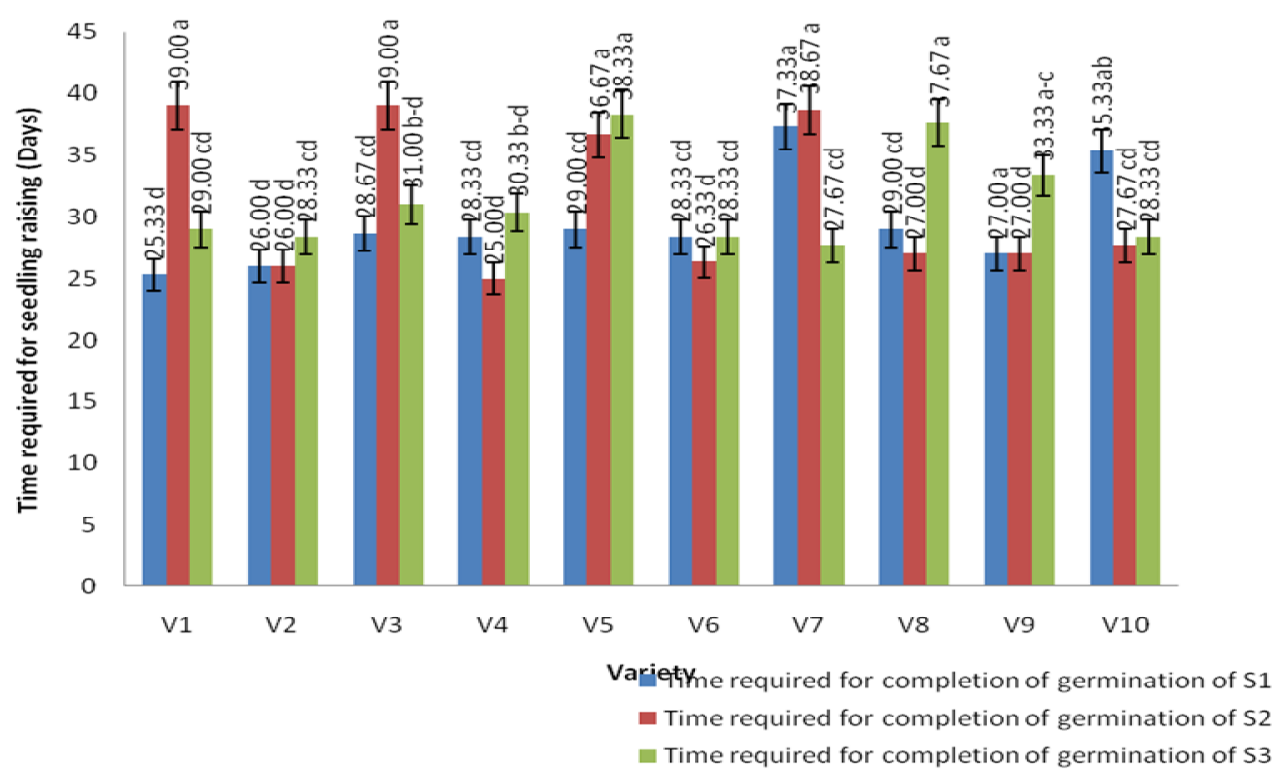

Figures followed by same letter(s) are statistically similar as per LSD at $5 \%$.

Figure 1. Interaction effect of accession sand pot mixture on the time required for completion of germination 
Table 2. Number of leaves after 6 and 12 months for different accessions

\begin{tabular}{lcc}
\hline Variety & Number of leaves after 6 months & Number of leaves after 12 months \\
\hline $\mathrm{V}_{1}$ & 3.000 & $4.56 \mathrm{a}$ \\
$\mathrm{V}_{2}$ & 2.89 & $3.44 \mathrm{de}$ \\
$\mathrm{V}_{3}$ & 2.89 & $4.44 \mathrm{ab}$ \\
$\mathrm{V}_{4}$ & 2.89 & $3.67 \mathrm{c}-\mathrm{e}$ \\
$\mathrm{V}_{5}$ & 2.78 & $3.89 \mathrm{~cd}$ \\
$\mathrm{~V}_{6}$ & 3.11 & $4.11 \mathrm{a}-\mathrm{c}$ \\
$\mathrm{V}_{7}$ & 3.00 & $3.78 \mathrm{~cd}$ \\
$\mathrm{~V}_{8}$ & 2.56 & $3.22 \mathrm{e}$ \\
$\mathrm{V}_{9}$ & 3.11 & $3.89 \mathrm{~cd}$ \\
$\mathrm{~V}_{10}$ & 2.89 & $4.00 \mathrm{bc}$ \\
\hline LSD & - & 0.46 \\
$\% \mathrm{CV}$ & 16.29 & 12.51 \\
Level of significance & $\mathrm{NS}$ & $* *$ \\
\hline
\end{tabular}

** NS denotes significant at $1 \%$ level of significance and non-significant, respectively.

Figures followed by same letter(s) are statistically similar.

Table 3. Number of leaves after 6 and 12 months for different pot mixture

\begin{tabular}{lll}
\hline Pot mixture & Number of leaves after 6 months & \multicolumn{1}{c}{ Number of leaves after 12months } \\
\hline $\mathrm{S}_{1}$ & 2.80 & 3.93 \\
$\mathrm{~S}_{2}$ & 3.03 & 4.00 \\
$\mathrm{~S}_{3}$ & 2.90 & 3.77 \\
\hline LSD $_{0.05}$ Value & - & - \\
$\%$ CV & 16.29 & 12.51 \\
Level of Significance & $\mathrm{NS}$ & $\mathrm{NS}$ \\
\hline
\end{tabular}

$\mathrm{S}_{1}=$ Sand: Cow dung=1:1, $\mathrm{S}_{2}=$ Soil: Cow dung=1:1, $\mathrm{S}_{3}=$ Sand: Soil: Cow dung=1:1:1.

NS denotes non-significant.

\subsection{Number of leaves after 6 and 12 months} At the end of $6^{\text {th }}$ months of the study, the highest no. of leaves were found in $\mathrm{V}_{6}(3.11), \mathrm{V}_{9}$ (3.11), $\mathrm{V}_{1}$ (3.00) and $\mathrm{V}_{7}$ (3.00) (Table 2). On the other hand, the lowest no. of leaves was observed in $\mathrm{V}_{8}$ (2.56). In case of the number of leaves, there is no significant difference among the pot mixtures (Table 3). After 12 months, the highest number of leaves were found in $\mathrm{V}_{1}$ (4.56), $\mathrm{V}_{3}$ (4.44) and $\mathrm{V}_{6}$ (4.11) (Table 2). Deglet Nour (UAE) was statistically identical with Deglet Nour (Saudi)) and Nagal. On the other hand, the lowest number of leaves was observed in Farida. In case of the number of leaves, there was no significant difference among the pot mixtures. The highest no. of leaves was found in the combination of variety United Arab Emirate and Sand: Soil: Cow dung=1:1:1, and the lowest no. of leaves was observed in the combination of variety Farida and treatment Sand: Cow dung $=1: 1$ (Table 4). In a study the number of leaves observed in Arabian date palms were 3.3, 3.7, 4.7 after 9, 12 and 18 months respectively, (Sherif et al., 2010). These variations may be due to the varietal differences and climatic factors.

\subsection{Plant height after 6 and 12 months}

After 6 months the tallest plants were measured in $\mathrm{V}_{2}$, and $\mathrm{V}_{4}, \mathrm{~V}_{5}, \mathrm{~V}_{9}$ and $\mathrm{V}_{10}$. After 12 months, the tallest plants were obtained in $\mathrm{V}_{2}, \mathrm{~V}_{3}, \mathrm{~V}_{5}, \mathrm{~V}_{7}$ and $V_{10}$ (Figure 2). After 6 and 12 months, the 
tallest plant was found in Soil: Cow dung $=1: 1$, which was statistically similar with Sand: Cow dung $=1: 1$. The palm grows at the rate of 1 to $1.5 \mathrm{ft}(30-45 \mathrm{~cm})$ a year and can reach 20 feet in
15 to 20 years depending on the cultivar and soil and water conditions (Morton, 1987). This result indicates that Bangladeshi soil is also appropriate for optimum growth of Arabian date palm.

Table 4. Interaction effects of accessions and pot mixture on the number of leaves after 6 and 12 months

\begin{tabular}{|c|c|c|c|}
\hline Accession & $\begin{array}{c}\text { Treatment } \\
\text { combination }\end{array}$ & $\begin{array}{c}\text { Number of leaves after } \\
6 \text { months }\end{array}$ & $\begin{array}{c}\text { Number of leaves after } 12 \\
\text { months }\end{array}$ \\
\hline & $\mathrm{T}_{1}$ & $3.33 \mathrm{a}$ & $4.00 \mathrm{bcd}$ \\
\hline \multirow[t]{3}{*}{$\mathrm{V}_{1}$} & $\mathrm{~T}_{2}$ & $2.67 \mathrm{abc}$ & $4.67 \mathrm{ab}$ \\
\hline & $\mathrm{T}_{3}$ & $3.00 \mathrm{ab}$ & $5.00 \mathrm{a}$ \\
\hline & $\mathrm{T}_{1}$ & $3.00 \mathrm{ab}$ & $3.33 \mathrm{de}$ \\
\hline \multirow[t]{3}{*}{$\mathrm{V}_{2}$} & $\mathrm{~T}_{2}$ & $3.00 \mathrm{ab}$ & $4.00 \mathrm{bcd}$ \\
\hline & $\mathrm{T}_{3}$ & $2.67 \mathrm{abc}$ & $3.00 \mathrm{e}$ \\
\hline & $\mathrm{T}_{1}$ & $2.67 \mathrm{abc}$ & $4.33 \mathrm{abc}$ \\
\hline \multirow[t]{3}{*}{$\mathrm{V}_{3}$} & $\mathrm{~T}_{2}$ & $3.33 \mathrm{a}$ & $4.67 \mathrm{ab}$ \\
\hline & $\mathrm{T}_{3}$ & $2.67 \mathrm{abc}$ & $4.33 \mathrm{abc}$ \\
\hline & $\mathrm{T}_{1}$ & $3.00 \mathrm{ab}$ & $3.67 \mathrm{cde}$ \\
\hline \multirow[t]{3}{*}{$\mathrm{V}_{4}$} & $\mathrm{~T}_{2}$ & $3.00 \mathrm{ab}$ & $4.00 \mathrm{bcd}$ \\
\hline & $\mathrm{T}_{3}$ & $2.67 \mathrm{abc}$ & $3.33 \mathrm{de}$ \\
\hline & $\mathrm{T}_{1}$ & $2.00 \mathrm{c}$ & $3.67 \mathrm{cde}$ \\
\hline \multirow[t]{3}{*}{$\mathrm{V}_{5}$} & $\mathrm{~T}_{2}$ & $3.33 \mathrm{a}$ & $4.00 \mathrm{bcd}$ \\
\hline & $\mathrm{T}_{3}$ & $3.00 \mathrm{ab}$ & $4.00 \mathrm{bcd}$ \\
\hline & $\mathrm{T}_{1}$ & $3.33 \mathrm{a}$ & $4.33 \mathrm{abc}$ \\
\hline \multirow[t]{3}{*}{$\mathrm{V}_{6}$} & $\mathrm{~T}_{2}$ & $3.00 \mathrm{ab}$ & $4.33 \mathrm{abc}$ \\
\hline & $\mathrm{T}_{3}$ & $3.00 \mathrm{ab}$ & $3.67 \mathrm{cde}$ \\
\hline & $\mathrm{T}_{1}$ & $3.00 \mathrm{ab}$ & $4.67 \mathrm{ab}$ \\
\hline \multirow[t]{3}{*}{$\mathrm{V}_{7}$} & $\mathrm{~T}_{2}$ & $2.67 \mathrm{abc}$ & $3.33 \mathrm{de}$ \\
\hline & $\mathrm{T}_{3}$ & $3.33 \mathrm{a}$ & $3.33 \mathrm{de}$ \\
\hline & $\mathrm{T}_{1}$ & $2.33 \mathrm{bc}$ & $3.00 \mathrm{e}$ \\
\hline \multirow[t]{3}{*}{$\mathrm{V}_{8}$} & $\mathrm{~T}_{2}$ & $3.00 \mathrm{ab}$ & $3.33 \mathrm{de}$ \\
\hline & $\mathrm{T}_{3}$ & $2.33 \mathrm{bc}$ & $3.33 \mathrm{de}$ \\
\hline & $\mathrm{T}_{1}$ & $2.67 \mathrm{abc}$ & $4.67 \mathrm{ab}$ \\
\hline \multirow[t]{3}{*}{$\mathrm{V}_{9}$} & $\mathrm{~T}_{2}$ & $3.33 \mathrm{a}$ & $3.33 \mathrm{de}$ \\
\hline & $\mathrm{T}_{3}$ & $3.33 \mathrm{a}$ & 3.67 cde \\
\hline & $\mathrm{T}_{1}$ & $2.67 \mathrm{abc}$ & 3.67 cde \\
\hline \multirow[t]{2}{*}{$\mathrm{V}_{10}$} & $\mathrm{~T}_{2}$ & $3.00 \mathrm{ab}$ & $4.33 \mathrm{abc}$ \\
\hline & $\mathrm{T}_{3}$ & $3.00 \mathrm{ab}$ & $4.00 \mathrm{bcd}$ \\
\hline LSD $_{0.05}$ value & & 0.775 & 0.797 \\
\hline$\% \mathrm{CV}$ & & 16.29 & 12.51 \\
\hline Level of significance & & $* *$ & $* *$ \\
\hline
\end{tabular}

$\mathrm{T}_{1}=$ Sand: Cow dung=1:1, $\mathrm{T}_{2}=$ Soil: Cow dung=1:1, $\mathrm{T}_{3}=$ Sand: Soil: Cow dung=1:1:1.

** denotes significant at $1 \%$ level of significance. Figures followed by same letter(s) are statistically similar as per LSD at $1 \%$. 


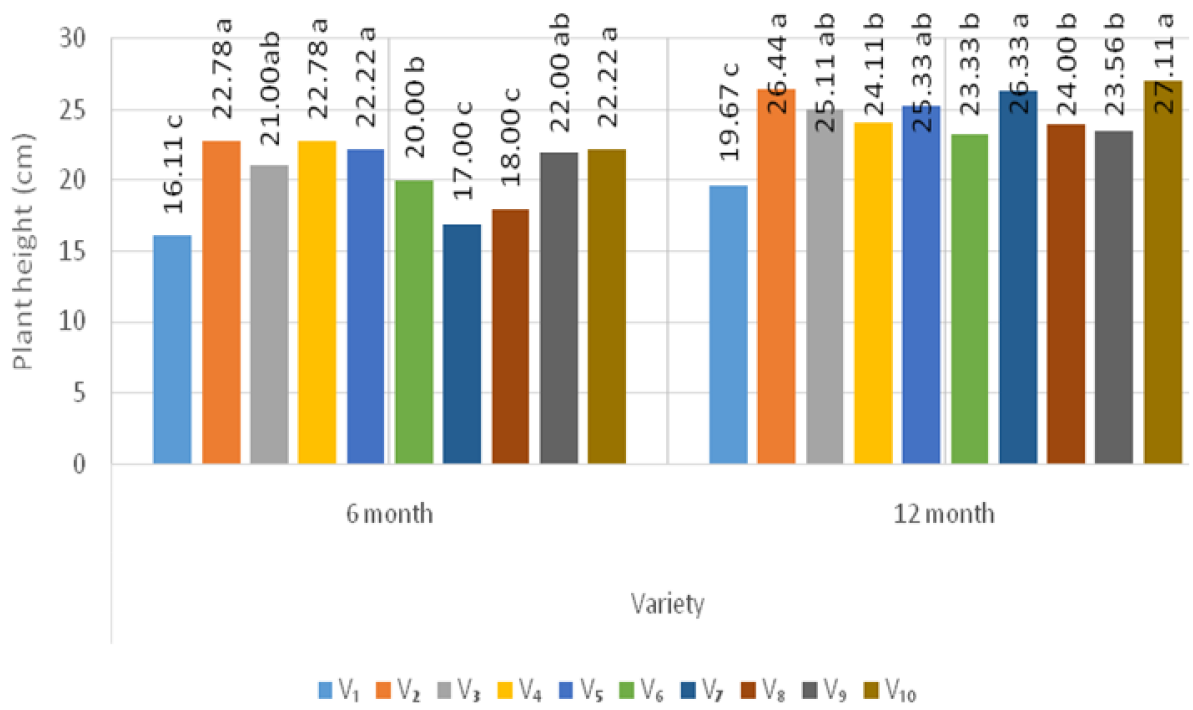

Figures followed by same letter(s) are statistically similar as per LSD at 5\%

Figure 2. Effect of accessions on plant height $(\mathrm{cm})$ after 6 and 12 months of study

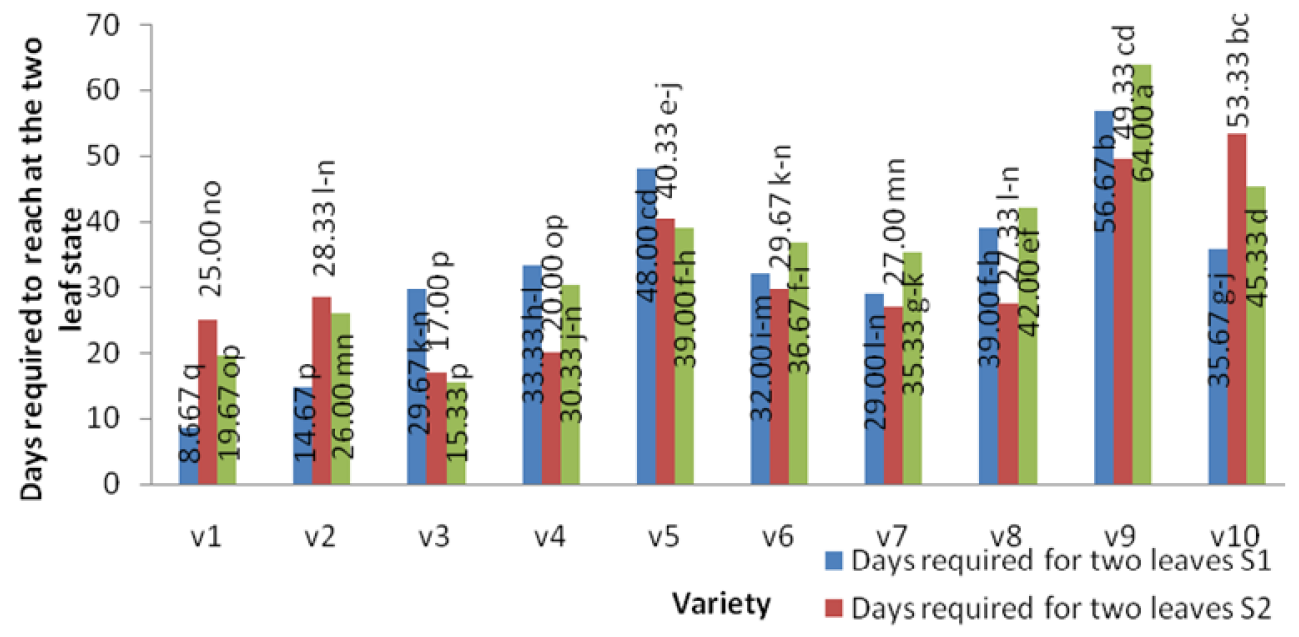

$\mathrm{S}_{1}=$ Sand: Cow dung=1:1, $\mathrm{S}_{2}=$ Soil: Cow dung=1:1, $\mathrm{S}_{3}=$ Sand: Soil: Cow dung=1:1:1.

Figures followed by same letter(s) are statistically similar as per LSD at $5 \%$.

Figure 3. Interaction effects of accessions and pot mixture for days required to attain the two leaf state 


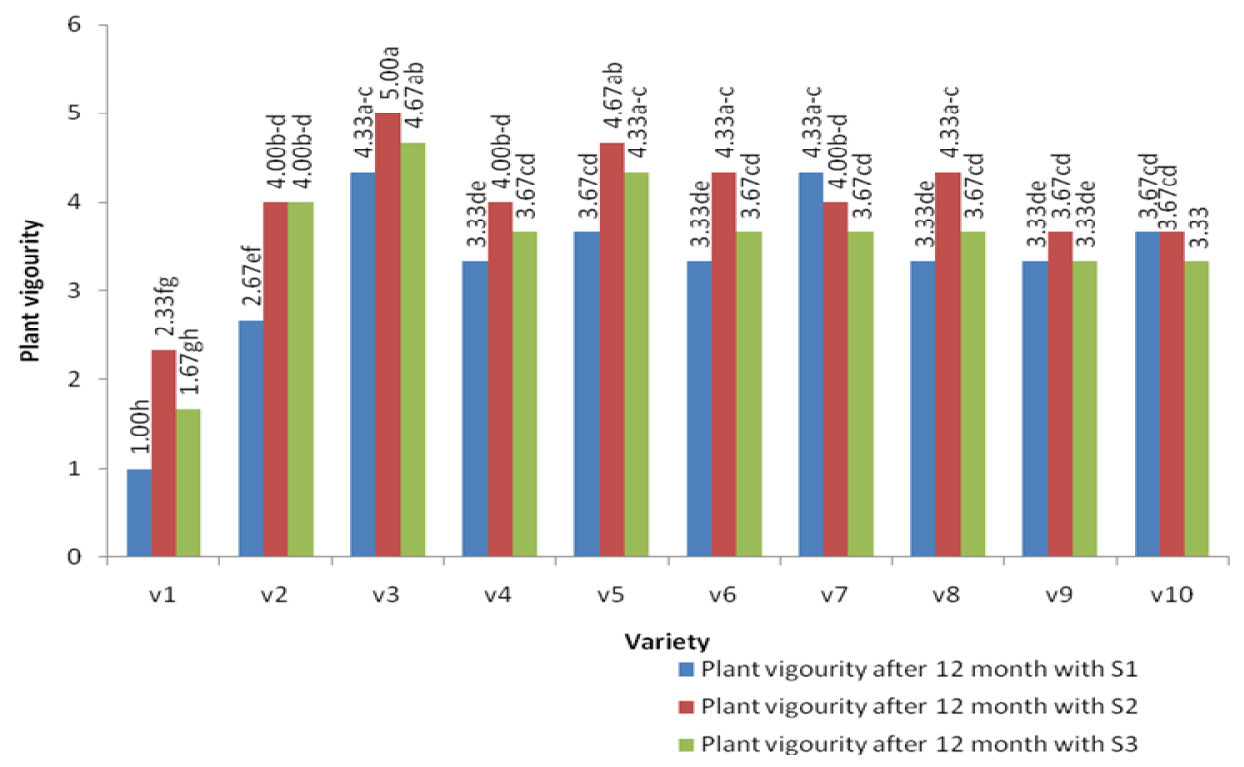

$\mathrm{S}_{1}=$ Sand: Cow dung=1:1, $\mathrm{S}_{2}=$ Soil: Cow dung=1:1, $\mathrm{S}_{3}=$ Sand: Soil: Cow dung=1:1:1.

Figures followed by same letter(s) are statistically similar as per LSD at $5 \%$.

Figure 4. Interaction effects of accessions and pot mixture on sapling vigour after 12 months

\subsection{Days required to attain two leaf state}

The least number of days required for attaining 2 leaf stage was in $V_{1}$ and $V_{3}$, while the highest number of days was required $\mathrm{V}_{9}$ (Figure 3 ). The lowest number of days required for that was in Soil: Cow dung $=1: 1$ but the highest number of days required for that was in Sand: Soil: Cow dung $=1: 1: 1$. These variations may be due to their genetic makeup and climatic factors in the studied area.

\subsection{Plant vigour (5 scale) after 12 months}

The highest plant vigour after 12 months was in the accession of $V_{3}$ and $V_{5}$ while the lowest plant vigour was found from the accession $V_{1}$ (Figure 4). The lowest plant vigour after 12 months was obtained from the soil $\mathrm{S}_{1}$ (Sand: Cow dung=1:1) and the highest plant vigour after 12 months was from soil $\mathrm{S}_{2}$ (Soil: Cow dung=1:1). Because date palms grow on different types of soils, the best performance can be achieved in sandy loam soils
(Naturland, 2002). Similarly, Morton (1987) reported that date grows well in sand, sandy loam, clay and other heavy soils.

\section{Conclusions}

From the preliminary observation, it could be concluded that Bangladeshi soil is also appropriate for optimum growth of Arabian date palms and Deglet Nour (Saudi). Marium (Algeria) and Normal were the most promising varieties in term of preliminary performance, while those of the accession no. $V_{1}$ (Deglet Nour from United Arab Emirates), $V_{2}$ (Deglet Nour from Algeria) and $\mathrm{V}_{10}$ (Dubai small) were unsatisfactory. In case of germination media, soil: cow dung (1:1) was the best as the germinating medium while the other two media was not satisfactory. However, further study is needed to find out the probability and prospect of growing date palms under the climatic conditions of Bangladesh. 


\section{References}

Al-Hooti, S., Sidhu, J. S. and Qabazard, H. 1997. Physico-chemical characteristics of five date fruit cultivars grown in the United Arab Emirates. Plant Foods for Human Nutrition, 50:101-113.

Amin, M., Zafar, M. S. and Anjum, A. Y. 2007. Potential of Date Export. In: Hortimag Newsletter (June, 2007). Pakistan Horticulture Development and Export Board, 9 p.

Askari, E., Al-Khalifa, N. S., Ohmura, T., AlHafedh, Y. S., Khan, F. A., Al-Hindi, A. and Okawara, R. 2003. Molecular phylogeny of seven date palm (Phoenix dactylifera L.) cultivars by DNA fingerprinting. Pakistan Journal of Botany, 35(3):323-330.

Baaziz, M. K., Majourhat, K., Bendiab. 2000. Date palm culture in the Maghreb countries: constraints and scientific research. Proceeding of the Date Palm International Symposium, Windhoek, Namibia, 2 2-26 February: 306-311 pp.

Biswas, P. K. 1987. A study on the relative merits of mixed cropping under two levels of irrigations. M.Sc. Thesis. Department of Agronomy, Bangladesh Agricultural University, Mymensingh, $18 \mathrm{p}$.

Botes, A. and Zaid A. 2002. The economic importance of date production and international trade In: Zaid A, (ed.). Date palm cultivation. FAO Plant Production and Protection Paper no. 156. Rome: Food and Agriculture Organisation of the United Nations, 45-56 pp.

Chao, C. T. and Krueger, R. R.. 2007. The date palm (Phoenix dactylifera L.): overview of biology, uses and cultivation. Hort Science, 42:1077-1082.
Iftekhar, M. S. and M. R. Islam. 2004. Managing mangroves in Bangladesh: A strategic analysis, Journal of Coastal Conservation, 10: 139-146 pp.

Islam, A. S. K., Miah, M. A. Q., Habib, M. A. and Moula, M. G. 2014. Performance of some mainland trees and palm species planted in the coastal islands of Bangladesh. Journal of Asiatic Society of Bangladesh, Science. 40(1): 9-15.

Milne, D. 1918. The Date Palm (Phoenix dactylifera) and its Cultivation in the Punjab. Thacker, Spink and Co., Calcutta. 111-112 pp.

Mohammad, S., Shabana, H. R. and Mawlood, E. A. 1983. Evaluation and identification of Iraqi date cultivars: Fruit characteristics of 50 cultivars. Date Palm Journal, 2:2755 .

Morton, J. 1987. Date. In: Fruits of warm climates. Miami, FL. 5-11 pp.

Naturland, E. V. 2002. Organic Farming in the Tropics and Subtropics: Special information about organic Date Palm Cultivation section. 82166 Grafelfing, Germany.

Sherif, F. El-Sharabasy and Zeinab E. Zaid. 2010. Effect of plant growth regulators on the development of ex vitro date palm (Phoenix dactylifera L.) Barhi cv. Plantlets. Arab Journal of Biotechnology, 13(1):35-46.

Zohary, D. and Hopf, M. 2000. Domestication of plants in the Old World. 3rd ed. OxfordUniversity Press, UK. 